\section{Tomáš Kocman}

Tomáš Kocman Tehnički muzej u Brnu kocman@technicalmuseum.cz

Stručni rad / Professional paper

Primljen / Received: 23. 2. 2021 UDK: 629.341:[069:62(437.3 Brno) DOI: https://doi.org/10.17018/portal.2021.10

\title{
Konzervatorsko-restauratorski radovi na autobusu Karosa ŠL 11.1305 iz Zbirke javnog gradskog prijevoza Tehničkog muzeja u Brnu
}

SAŽETAK: Zbirka javnog gradskog prijevoza u Tehničkom muzeju u Brnu osnovana je 1970. godine. Temelj kolekcije čini više od sto vozila - muzejskih izložaka - tramvaja (motornih kola i prikolica), trolejbusa, autobusa te autobusnih prikolica. U manjoj mjeri su zastupljene i parne i električne lokomotive, željeznička kola te specijalna radna kola. Navedeni predmeti zahtjevaju sasvim drugačiji pristup, koji se umnogome razlikuje od prakse ostalih muzejskih područja. S obzirom na velike dimenzije zahtijevaju i posebne uvjete čuvanja. Ne treba zanemariti ni njihovu veliku težinu, što ima posebnu važnost pri manipulaciji ako se vozila ne mogu kretati na vlastitim osovinama. Zbog toga su postupci konzervatorsko-restauratorskih radova na tim muzejskim predmetima vrlo specifični, što se najbolje očituje na odabranom primjeru - autobusu Karosa ŠL 11.1305.

KLJUČNE RIJEČI: tehnički muzej, javni prijevoz, tramvaj, trolejbus, autobus, starodobno vozilo, konzerviranje, restauriranje

$\Lambda$ utobus Karosa ŠL 11.1305 u zbirci Tehničkog muzeja u Brnu prvi je tip autobusa kod kojeg je u postupku proizvodnje korištena tehnologija izrade uz upotrebu zasebnih panela. ${ }^{1}$ Ti su paneli izrađivani zasebno te bi se njihovim spajanjem sastavljao autobus. Ta je tehnologija nastala u ondašnjem Narodnom poduzeću Karosa Vysoké Mýto tijekom druge polovice šezdesetih godina 20. stoljeća, kada je počela izrada prvih autobusa Karosa Š 11. Sačuvano je vozilo jedan od prvih autobusa namijenjenih regionalnom prijevozu iz voznog parka Čehoslovačkog državnog autobusnog prijevoznika ČSAD. Od novijih autobusa tog tipa razlikuje se, prije svega, po dvodijelnim odbojnicima i kutiji iznad prednjih vrata za izmjenjivi prikaz odredišta (sl. 1). 


\begin{tabular}{|l|l|}
\hline \multicolumn{2}{|l|}{ Osnovni podaci o autobusu } \\
\hline Tvornica & Karosa národní podnik, Vysoké Mýto \\
\hline Tip autobusa & Karosa ŠL 11.1305 \\
\hline Godina proizvodnje & 1971. \\
\hline Tvornički broj & 1658 \\
\hline Masa & $8370 \mathrm{~kg}$ \\
\hline Najveća brzina & $100 \mathrm{~km} / \mathrm{h}$ \\
\hline Dužina & $11095 \mathrm{~mm}$ \\
\hline Širina & $2500 \mathrm{~mm}$ \\
\hline Visina & $3120 \mathrm{~mm}$ \\
\hline Kapacitet sjedala & 45 putnika \\
\hline Ukupan broj mjesta & 75 putnika \\
\hline Broj osovina & 2 \\
\hline Međuosovinsko rastojanje & $5500 \mathrm{~mm}$ \\
\hline Kočioni sustav & pneumatska kočnica, parkirna i motorna kočnica \\
\hline Tip dizelskog motora & LIAZ ML 634 / vodom hlađeni, ležeći, 6-cilindarski redni motor s direktnim ubrizgavanjem goriva \\
\hline Snaga motora & $149 \mathrm{~kW}$ \\
\hline Volumen motora & $11940 \mathrm{~cm}{ }^{3}$ \\
\hline Mjenjač & ručni s pet stupnjeva Praga 5P80 \\
\hline
\end{tabular}
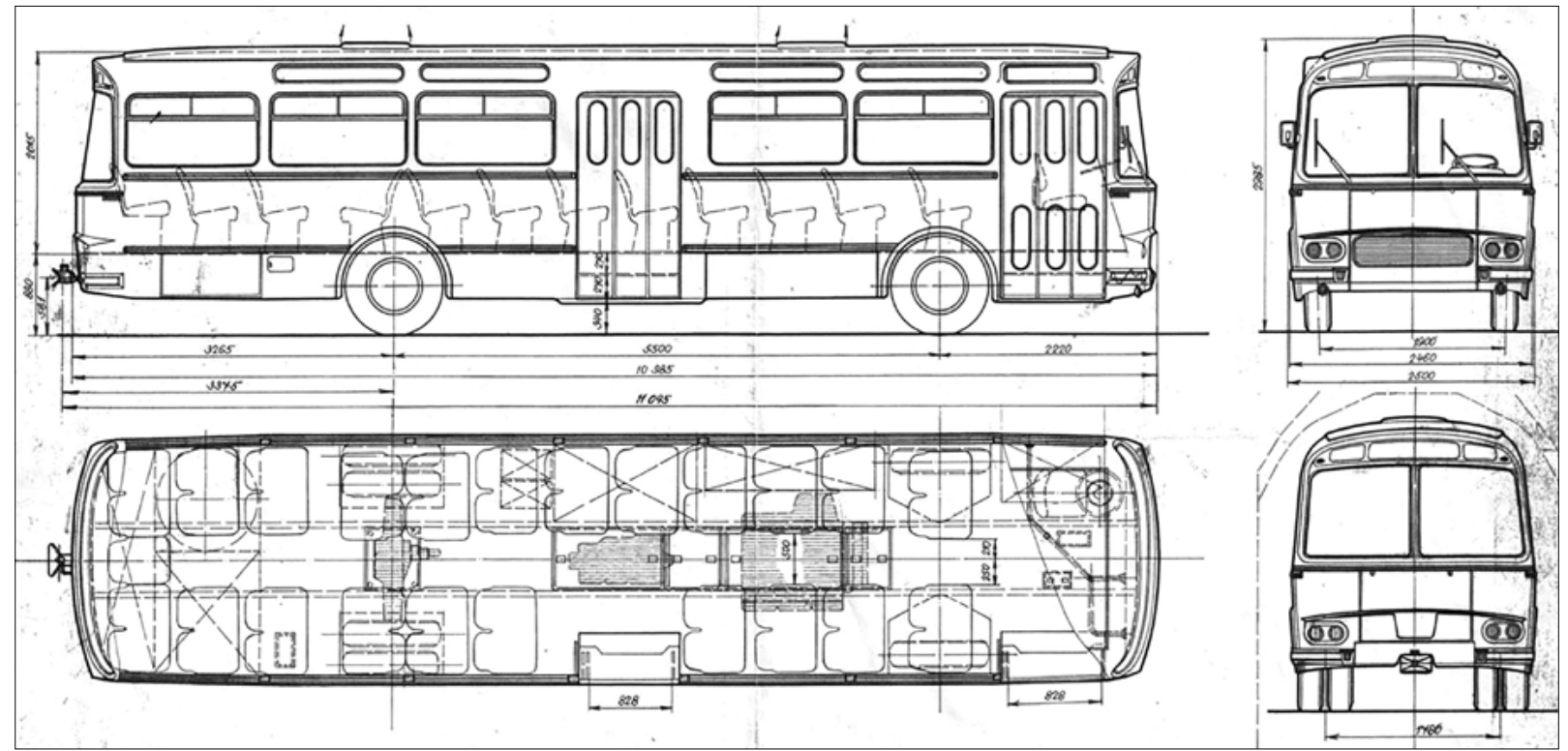

1. Tehnički nacrt autobusa Karosa ŠL 11.1305 (TMB, snimka: T. Kocman, 2004.)

Blueprint of the Karos ŠL 11.1305 bus (TMB, T. Kocman, 2004)

\section{Konzervatorsko-restauratorski radovi na vozilima javnoga gradskog prijevoza}

Muzejska vozila javnog gradskog prijevoza (JGP-a) specifična su i po konzervatorsko-restauratorskim postupcima. Uzrok tomu svakako su već navedene goleme dimenzije tih predmeta, ali i zahtjevno rukovanje, primjerice nužnost postojanja tračničke veze $u$ restauratorskoj radionici. Konstrukcija vozila javnog prijevoza uključuje mnoštvo sastavnih dijelova različitih namjena i oblika, a za svaki su potrebni samostalni konzervatorsko-restauratorski postupci. Zbog toga se radovi izvode prije svega u stručnim radionicama, u kojima se popravljaju i pregledavaju tramvaji, trolejbusi ili autobusi, jer one imaju i potrebne uvjete i tehnologiju, i stručne, marljive i motivirane radnike za obavljanje restauratorskih postupaka na muzejskim vozilima (sl. 2).

U Češkoj, primjerice, postoje Krnovske remontne radionice i tvornice strojeva, trvrtke Ekova Electric u Ostravi, Prometno poduzeće Zlín-Otrokovice, Zliner ili Gradsko prometno poduzeće u Brnu (centralna radionica Medlánky, radionica generalnih popravaka na trolejbusnoj remizi 
Komín). Vrlo je iskusan restaurator Vlastimil Urbánek. Njegova je tvrtka u selu Lhota nad Moravou, u blizini grada Litovela, poznata po restauranju muzejskih autobusa, posebice onih marke Škoda 706 RTO. U prošlosti je Urbanek restaurirao muzejske autobuse za poduzetnika Martina Uhra ili Gradsko prometno poduzeće grada Plzeňa. Urbanek također surađuje na restauriranju garnutire autobusa Jelcz 272 MEX s prikolicom Jelcz PO1 (sl. 3).

Restauriranje starodobnih vozila javnog prijevoza zahtijeva, u prosjeku, oko 5000 sati rada te ukupne troškove od 2,5 milijuna čeških kruna (100 000 eura) kada je riječ o restauriranju autobusa, a u slučaju restauranja tramvajskih motornih kola do 6 milijuna čeških kruna (240 000 eura). Konzervatorsko-restauratorski radovi na vozilima javnog gradskog prijevoza primarno se financiraju sredstvima Tehničkog muzeja. Međutim, s obzirom na ostale djelatnosti muzeja, ta sredstva nisu dovoljna, pa Tehnički muzej dijelom koristi sredstva iz programa ISO (Integrirani sustav zaštite) Ministarstva kulture. Čsto je restauratorski zahvat potrebno provesti u više faza tijekom dužeg vremena, pa konzervatorsko-restauratorskih radovi iznimno dugo traju. Neki unikatni predmeti, primjerice tramvaj poljevačica iz 1928. godine, restauranje čekaju već pedesetak godina. Postupak restauranja starodobnih vozila vrlo je zahtjevan i, kod muzejskih predmeta, mora, biti vođen $u$ skladu s njihovom povijesnom, tehničkom i estetskom vrijednosti, a na početku je uvijek nužno razmotriti koji je konzervatorsko-restauratorski koncept najpovoljniji za konkretan artefakt. U slučaju muzejskih vozila sastavni je dio restauratorskog zahvata obnova njihove funkcije kako bi se javnosti predstavili $u$ voznom stanju (sl. 4).

\section{Provedba zakonskih odredaba na vozilima javnoga gradskog prijevoza}

Kao što je već navedeno, cilj konzerviranja i restauriranja muzejskih predmeta jest njihovo očuvanje za današnje i buduće generacije. Misija tehničkih muzeja također je promovirati značenje i razvitak pojedinih tehnologija $i$ znanja vezanih uz tehnološke postupke izrade sakupljenih tehničkih artefakta. Jedini, dugoročno mogući način prezentacije muzejskih vozila javnog prijevoza u kolekciji Tehničkog muzeja u Brnu, povremene su vožnje ulicama gradova, koje se odvijaju uz regularni promet. Kako bi starodobna vozila javnog prijevoza bilo moguće upotrebljavati na takav način, potrebno je poštovati stroge legislativne zahtjeve. Kada je riječ o autobusu, propisani su godišnji, redovni tehnički pregledi te kontrola emisije štetnih plinova $u$ atmosferi. Kako bi vozila starija od trideset godina, dobila status povijesnih, s posebnim registacijskim brojem, mora ih testirati klupska i županijska komisija za testiranje starodobnih vozila. ${ }^{2}$

$\mathrm{U}$ okviru testiranja procjenjuje se i povijesna originalnost, kao i tehničko stanje vozila. ${ }^{3}$ Pravila za tračnička

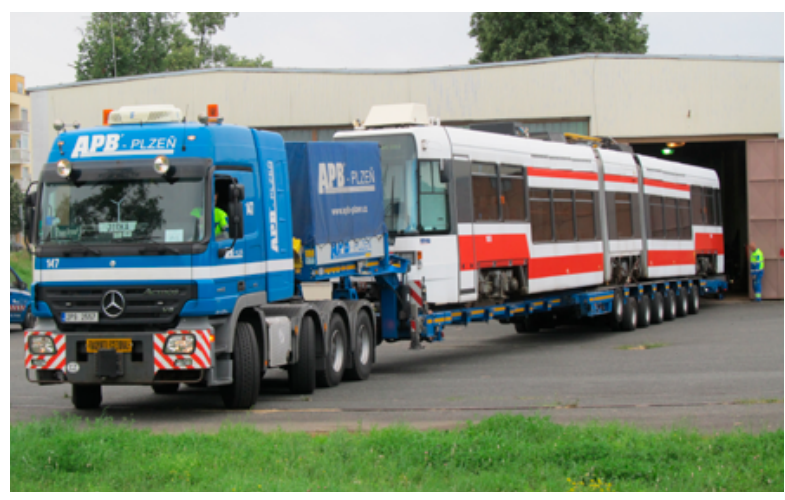

2. Tramvaj ČKD RT6N izrađen 1997. godine tijekom istovara iz specijalnih kola u depou Tehničkog muzeja u Brnu 22. lipnja 2018. godine (TMB, snimka: T. Kocman, 2018.)

Tram ČKD RT6N, made in 1997, during unloading from special cars in the depot of the Technical Museum in Brno on June 22, 2018 (TMB, T. Kocman, 2018)

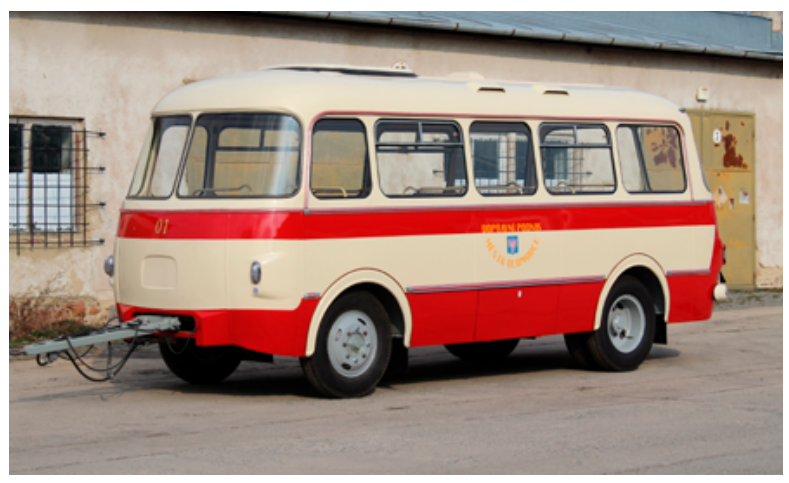

3. Autobusna prikolica Jelcz PO1 iz 1972. godine. Konzervatorskorestauratorske radove izveo je Vlastimil Urbánek u suradnji s Prometnim poduzećem grada Brna i radionicom Metodičkog centra za konzervaciju Tehničkog muzeja u Brnu u Řečkovicama (TMB, snimka: T. Kocman, 2019.)

Jelcz PO1 bus trailer of 1972. Conservation was carried out by Vlastimil Urbánek in cooperation with the Transport Company of the City of Brno and the workshop of the Methodological Centre for Conservation of the Technical Museum in Brno, in Řečkovice (TMB, T. Kocman, 2019)

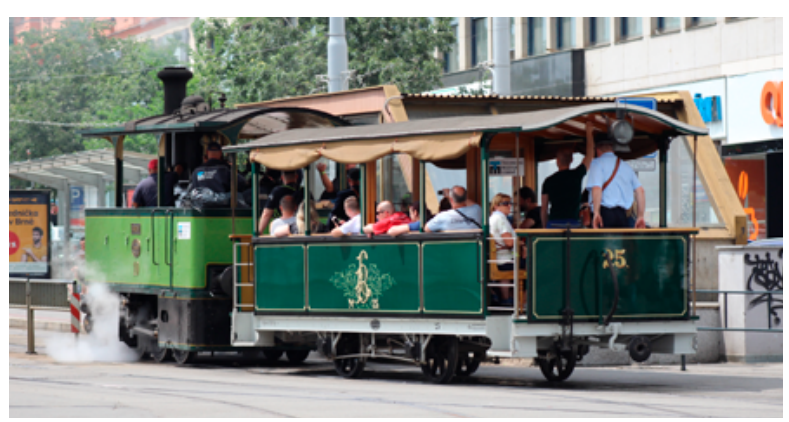

4. Parna tramvajska lokomotiva Caroline s prikolicom broj 25 našla se u središtu pozornosti javnosti za vrijeme proslave 150. obljetnice tramvajskog prometa u Brnu 2019. godine (TMB, snimka: T. Kocman, 2019.)

Caroline steam tram locomotive with trailer number 25 was in the public spotlight during the celebration of the $150^{\text {th }}$ anniversary of tram traffic in Brno in 2019 (TMB, T. Kocman, 2019) 


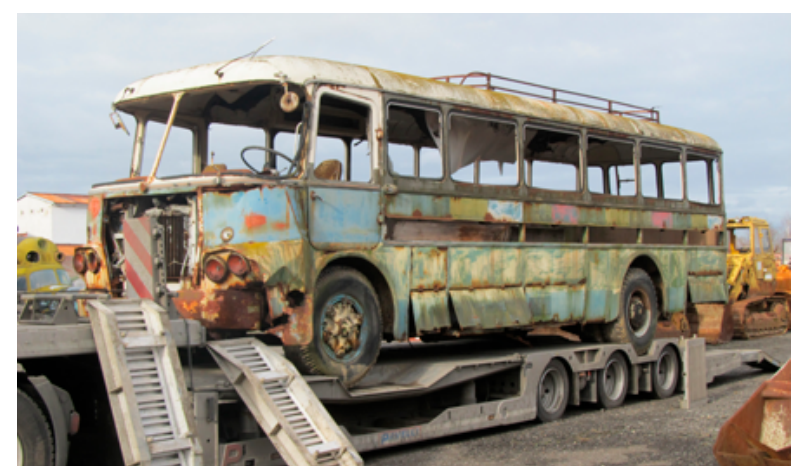

5. Tehnički muzej u Brnu za svoju je zbirku nabavio autobus Ikarus 630 iz 1967. godine. Sadašnje stanje ovog autobusa može se vidjeti na slici iz siječnja 2015. tijekom njegova odlaska od zadnjeg vlasnika u češkom gradu Píseku. (TMB, snimka: T. Kocman, 2015.) The Technical Museum in Brno purchased a 1967 Ikarus 630 bus for its collection. The current condition of this bus can be seen in a picture from January 2015 during its departure from its last owner in the Czech city of Písek. (TMB, T. Kocman, 2015)

vozila (željezničke lokomotive i kola, tramvajska kola te trolejbuse), uređena su Zakonom o prugama broj 466/1994, u kojem je određeno da se u slučaju starodobnih kola, neke njegove odredbe mogu koristiti proporcionalno. Najprije određena pravna osoba treba ispitati utvrđeni tehnički uređaj, električni i zračni (pneumatski), kako bi se, na temelju zapisnika o provjeri utvrđenog tehničkog uređaja, u Uredu za pruge moglo zatražiti izdavanje knjižice o ispravnosti utvrđenog tehničkog uređaja. Električna oprema vozila dobiva jednu knjižicu o ispravnosti, dok kod zračne (pneumatske) opreme, posebnu knjižicu o ispravnosti dobiva svaki spremnik zraka u vozilu. ${ }^{4}$ Kotao parne lokomotive specifična je tehnička naprava. Svake je godine potrebno obaviti njegov pregled te ga isprobati visokim pritiskom vode. Svakih šest godina treba izvaditi dio cijevi te, ovisno o njihovu stanju, odlučiti o nužnim popravcima, poput, primjerice, zamjene ostalih cijevi. ${ }^{5}$ Zatim se muzejska kola podvrgavaju tehničko-sigurnosnoj probi, čiji je sastavni dio provjera funkcije motornih i parkirnih kočnica te kočnica za nuždu. Za svaki su način kočenja propisane veličine najveće udaljenosti kočenja i usporavanja. Prijedlog za restauriranje svakog muzejskog vozila mora uzeti u obzir sve navedene uvjete za budući muzejski promet, kao i stanje u kojem se predmet nalazi na početku radova.

\section{Zatečeno stanje vozila prije preuzimanja u zbirku}

Tehnički je muzej većinu vozila javnog prijevoza preuzeo nakon što su rashodovana. Riječ je o vozilima na kraju svog životnog vijeka čiji su dijelovi vrlo istrošeni. Korozija osobito ugrožava kolni ormar, pri čemu ne stradaju samo vanjske limene oplate nego i bitni nosivi dijelovi kostura. Ako se radi o vozilu koje je dugoročno uklonjeno iz prometa te godinama izloženo utjecaju vanjske sredine

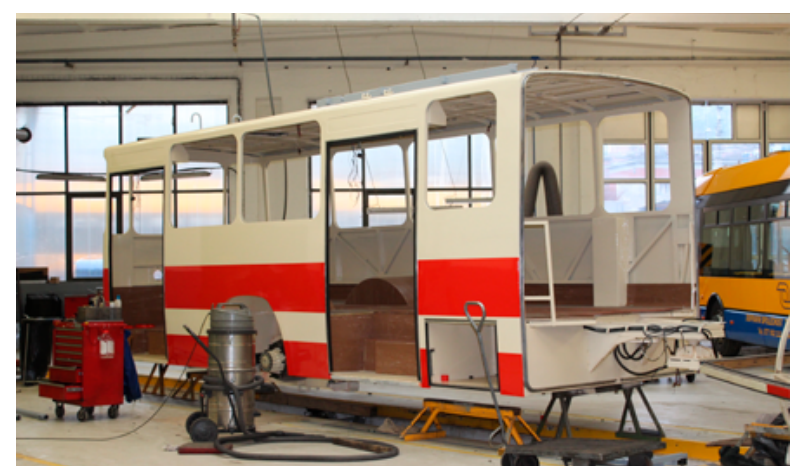

6. U listopadu 2019. godine započeli su konzervatorskorestauratorski radovi na zglobnom trolejbusu Škoda Sanos. Na slici se vidi stanje kolnog ormara zadnjeg dijela trolejbusa nakon više od godine dana radova, 2. veljače 2021. (TMB, snimka: T. Kocman, 2021.)

Conservation on the Škoda Sanos articulated trolleybus began in October 2019. The picture shows the condition of the coachwork of the rear part of the trolleybus after more than a year of conservation, February 2, 2021. (TMB, T. Kocman, 2021)

i vremenskih uvjeta, degradacija kolnog ormara može biti znatna, a često nedostaje i niz važnih dijelova (motor, kolni slogovi, unutrašnja oprema). S druge strane, može biti riječ o mnogo starijim, unikatnim vozilima kod kojih su zahtjevni restauratorski radovi jedina mogućnost njihovog očuvanja za buduće generacije. U zbirci Tehničkog muzeja u Brnu postoji veći broj na sličan način restauriranih tramvajskih kola ili pak vozila iz novijeg razdoblja, kao što su autobusi Karosa T 500 HB, Karosa ŠL 11.1305, dok autobus Ikarus 630 još nije restauriran (sl. 5).

Dakle, za razliku od izložaka koje muzeji dobivaju od raznih privatnih vlasnika, poput, primjerice, garažiranog automobila prvog vlasnika, vozila javnog prijevoza nisu očuvana i predstavljena $u$ stanju $u$ kojem su stigla u muzejsku zbirku. Njihovo stanje može svjedočiti samo o nekim kasnijim preinakama, što smanjuje vrijednost muzejskih vozila u odnosu na izvornu konstrukciju, dizajn i tehnologiju izrade. Nije moguće zanemariti ni činjenicu da su vozila javnog prijevoza tijekom svoga vijeka prošla veći broj propisanih kontrola različitih stupnjeva, uključujući generalne popravke. Njihovo konzerviranje i restauriranje stoga je još jedan generalni popravak, koji se od ostalih razlikuje po nastojanju da se vozila, koliko je to god moguće, vrate u izvorno, starodobno stanje.

Vozilo sačuvano u stanju u kojemu je zatečeno, ne može dugotrajno odgovarati uvjetima tehničkih pregleda, ne može ispunjavati zahtjeve testiranja povijesnih vozila, a u slučaju električnih tračničkih vozila gubi sposobnost za promet zbog lošeg stanja kablova i izolacije električne opreme. Pa ipak, u zbirci Tehničkog muzeja ima nekih vozila javnog prijevoza koja su dosada sačuvana i djelomično konzervirana u stanju u kojem su zatečena. S obzirom na njihovo tehničko stanje, važno je što prije 
osigurati njihovu cjelovitu obnovu. Odluka o restauratorskim postupcima na muzejskim vozilima javnog prijevoza, a osobito odluka o stanju u koje će svaki restaurirani predmet biti doveden, posve je u nadležnosti kustosa zbirke.

Tehnički muzej u Brnu dugoročno nastoji, koliko je god moguće, svako vozilo javnog prijevoza vratiti u izvorno i vozno stanje. To proizlazi iz postavljenih okvira zbirke u kojoj bi za svako vozilo trebalo dokumentirati razinu konstrukcije i dizajna $u$ vremena $u$ kojem je nastalo i u kojem je počelo služiti putnicima. Pri restauriranju poljskog autobusa Jelcz 272 MEX iz 1974. godine i prototipa zglobnog trolejbusa Škoda s kolnim ormarom bivšeg jugoslavenskog autobusa Sanos iz 1982. godine, koje je upravo u tijeku, iz navedenih je razloga prioritet očuvanje ili vraćanje svih karakterističnih detalja (sl. 6).

Na temelju više od 50 godina iskustva Tehničkog muzeja u Brnu, stjecanog tijekom formiranja zbirke vozila javnog prijevoza, može se zaključiti kako se najboljim postupkom smatraju konzervatorsko-restauratorski radovi na konkretnom vozilu u obliku generalnog popravka i vraćanje u odgovarajući povijesni izgled. Uz to postoje analogije s postupcima restauriranja i očuvanja starodobnih automobila - oldtajmera. Slične je principe formulirala Međunarodna federacija za starodobna vozila FIVA (Fédération Internationale des Véhicules Anciens) u pojedinim člancima Torinske povelje. ${ }^{6}$ Torinska je povelja prihvaćena kao dokument Generalne skupštine FIVA-e u listopadu 2012. godine, a propisuje opće principe odgovarajućeg tretmana povijesnih vozila, među ostalim, i očuvanje izvornosti povijesnih vozila tijekom njihove uporabe, održavanja i restauriranja, što su pravila koja je Tehnički muzej u Brnu, tijekom dugogodišnje brige za zbirku muzejskih vozila javnog prijevoza, uvijek poštovao.

\section{Vrste konzervatorsko-restauratorskih radova}

Kao primjer, mogu se navesti konzervatorsko-restauratorski radovi na autobusu Karosa ŠL 11.1305. Tehnički muzej u Brnu dobio ga je 2004. godine; autobus je bio cjelovit, no dosta oštećen nakon dugotrajnog stajanja na zemljištu bivšeg vlasnika, u selu Oldřichovu u blizini grada Lipníka nad Bečvou, gdje je osobito stradao tijekom poplava 1997. godine. Zbog djelovanja vode, snijega i soli došlo je do nastanka korozije, koja je jako oštetila vanjsku limenu oplatu, kao i donji dio bočnih zidova. Na mnogim je mjestima čeličnog kostura i okvira bočnih zidova došlo do smanjenja slojeva materijala, a mjestimično su se već pojavili i otvori. Voda je, prodirući kroz razbijene prozore, oštetila i unutarnju opremu.

Konzervatorsko-restauratorski radovi na autobusu Karosa ŠL 11.1305 izvedeni su u razdoblju između 2004. i 2009. godine. Na restauratorskom zahvatu sudjelovali su zaposlenici Metodičkog centara za konzervaciju i radnici iz Gradskog prometnog poduzeća u Brnu. ${ }^{7}$ S namjerom ponovnog vraćanja u vozno stanje, autobusu je potpuno vraćen izgled koji je imao prije pola stoljeća, kad je proizveden.

\section{Restauriranje kolnog ormara}

Kolni ormar autobusa Karosa ŠL 11.1305 bio je potpuno ogoljen, što znači da je uklonjena sva unutarnja oprema (sjedala, rukohvati, oprema vozačke kabine, obloga zidova i krova). Bilo je važno izraditi fotodokumentaciju, pronaći tragove i nijanse originalnih boja, te sačuvati primjerke raznih gumenih i plastičnih dijelova. Svi slojevi starih boja i korozije uklonjeni su pjeskarenjem kostura kolnog ormara. Važno je naglasiti da je lak autobusa u zatečenom stanju bio potpuno atipičan i dosta oštećen. Shema boja nije odgovarala karakterističnom izgledu autobusa tog tipa namijenjenih za regionalni prijevoz $u$ tadašnjoj Čehoslovačkoj (sl. 7, 8 i 9). Da bi se spriječila nova korozija nakon pjeskarenja, kostur kolnog ormara odmah je obojen specijalnom bojom SIGMA WELD 120 koja sadrži cink te omogućuje kasnije restauratorske radove, primjerice zavarivanje.

\section{Bravarski i zavarivački radovi}

Slijedila je izmjena mehanički i korozijom oštećenih čeličnih profila, osobito u donijem dijelu bočnih zidova, oko blatobrana, kod okvira prozora, a također montaža nove limene oplate. Tijekom restauriranja kostura kolnog ormara većinom su iskorišteni standardni čelični kutni $U$ ili L profili, te zatvoreni profili. Za izradu nekih sastavnih dijelova specijalnog oblika bili su potrebni najsloženiji bravarski radovi. A Tehnički je muzej imao na raspolaganju još neke originalne dijelove, kao što su krila ulaznih vrata, odbojnici te prednji i stražnji panel kolnog ormara.

\section{Lakirerski radovi}

Početkom listopada 2006. godine završeni su limarski radovi pa je autobus Karosa ŠL 11.1305 prevezen u centralnu radionicu Gradskog prometnog poduzeća u Brnu radi lakiranja. Kustos je, na temelju iskustva i istraživanja slojeva sačuvanih boja, te usporedbe s postojećim fotografijama, odredio nijanse boja za lakiranje vozila. Tragovi originalnih boja pojavili su se oko vrata, ispod gumenih profila. Radilo se o karakterističnoj kombinaciji krem boje nijanse RAL $1015 \mathrm{~s}$ plavim pojasevima nijanse RAL 5015 oko vozila. Istodobno je bilo moguće izmjeriti širinu plavih pojaseva. Kvalitetan premaz laka vrlo je važan ne samo za budući izgled nego i za dugotrajnu zaštitu renoviranog vozila. Podrazumijeva se da lakiranje obuhvaća pažljivo kitanje i brušenje svih neravnina vanjske površine, a upotrijebljene su poliuretanske boje MULTIMIX RAL 1015 PUR i MULTIMIX RAL 5015 PUR.

\section{Pismoslikarski radovi}

S lijeve i desne vanjske strane autobusa naslikane su svijetloplave oznake bivšeg Čehoslovačkog državnog 


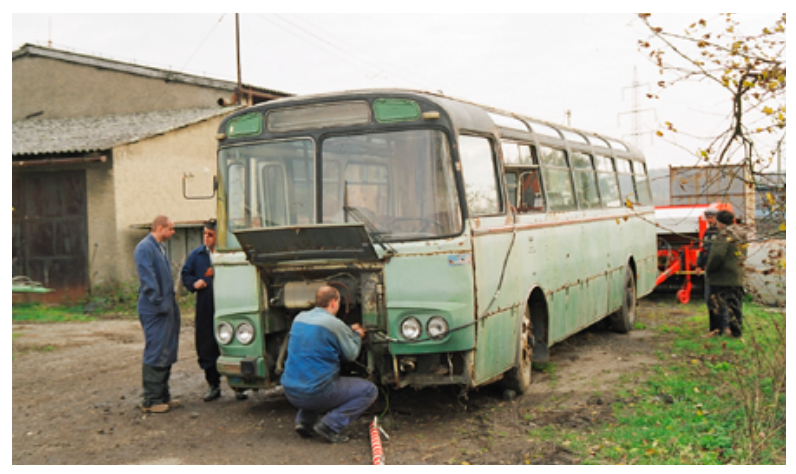

7. Autobus Karosa ŠL 11.1305 u selu Oldřichovu u studenome 2003. godine kada je pripreman za tegljenje u Brno (TMB, snimka: T. Kocman, 2003.)

The Karos ŠL 11.1305 bus in the village of Oldřichovo in November 2003, when it was being prepared to be towed to Brn. (TMB, T. Kocman, 2003)

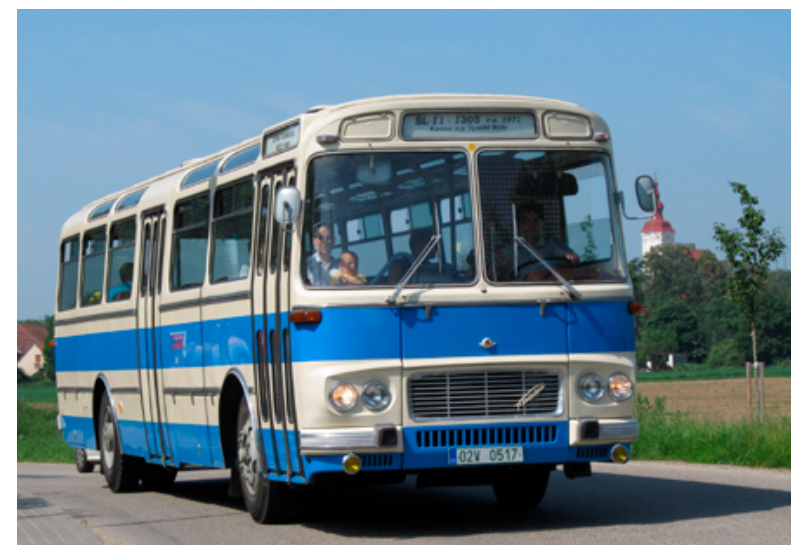

9. Autobusi Karosa ŠL 11 kao što je ovaj renovirani autobus ŠL 11.1305 smatraju se remek-djelom češkog dizajna ove vrste vozila javnog prijevoza (TMB, snimka: T. Kocman, 2018.) Karos ŠL 11 buses, like the renovated ŠL 11.1305 bus, are considered a masterpiece of Czech design for this type of publictransport vehicle (TMB, T. Kocman, 2018)

autobusnog prometnika s crvenim slovima ČSAD. Unutra su crnim slovima napisane upute za putnike, kao što je NEMLUVTE ZA JÍZDY S ŘIDIČEM (Ne razgovarajte $s$ vozačem za vrijeme vožnje) ili NOUZOVÝ VÝCHOD (Izlaz za nuždu), koja se nalazila iznad prozora pored kojih se nalaze specijalni čekići za njihovo razbijanje (sl. 10).

\section{Restauriranje pogonskog agregata}

Nakon lakiranja uslijedila je montaža pneumatske instalacije, usisnog sustava te kruga hlađenja motora. Istovremeno je nastavljeno restauriranje pojedinih dijelova pogona - dizelskog motora, mjenjača, kardana, kolnih slogova. U sredini kolnog ormara se ispod poda nalazi vodom hlađeni ležeći motor LIAZ ML 634. Taj je tip motora

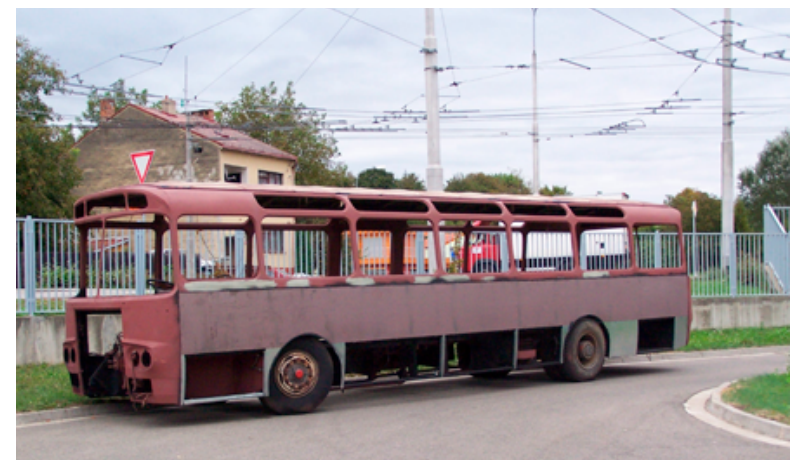

8. U listopadu 2006. godine u garaži Komín prijevoznog poduzeća grada Brna, završeni su konzervatorsko-restauratorski radovi na kosturu kolnog ormara autobusa Karosa ŠL 11.1305 (TMB, snimka: T. Kocman, 2006.)

Conservation of the frame of the coachwork of the Karos ŠL 11.1305 bus was completed in October 2006, in the garage of the Komín transport company of the city of Brno (TMB, T. Kocman, 2006)

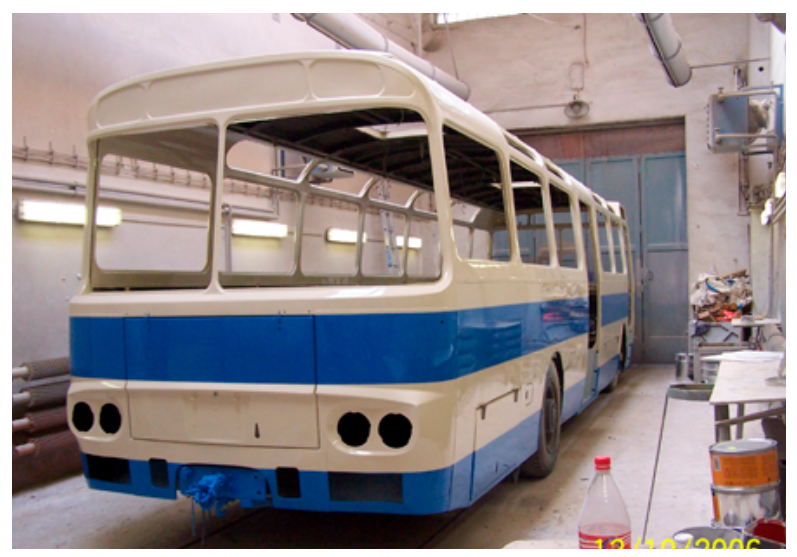

10. Lakiranje autobusa Karosa ŠL 11.1305 u centralnoj radionici Gradskog prometnog poduzeća u Brnu. Autobus je premazan krem bojom nijanse RAL 1015 s dva plava pojasa nijanse RAL 5015 (TMB, snimka: T. Kocman, 2006.)

Varnishing of the Karos ŠL11.1305 bus in the central workshop of the City Transport Company in Brno. The bus was coated with cream-coloured paint, shade RAL 1015, with two blue bands, shade RAL 5015 (TMB, T. Kocman, 2006)

proizvodio poznati češki proizvođač LIAZ Jablonec nad Nisou od kraja 60-ih godina sve do kraja 20. stoljeća u verzijama ML 634, ML 635 i ML $637 \mathrm{~s}$ turbo punjenjem. Motori LIAZ korišteni su za kamione Škoda 706 MTS, LIAZ 100, autobuse Karosa Š11, Karosa 700 i Karosa 900 , te za željeznička dvoosovinska motorna kola 810 , četveroosovinska motorna kola 842, dizelske dvoosovinske lokomotive 704 te četveroosovinske lokomotive 714 . Nakon 2000. godine nastavljena je proizvodnja vrlo sličnih motora u tvrtki TEDOM Třebíc. Restauriranje motora obavilo je Gradsko promento poduzeće u Brnu. Generalni popravak dizelskog motora LIAZ uključio je izmjenu brizgaljki, klipova, klipnih prstenova, klipnjača i osovina te su istodobno provjerili stanje koljenastog vratila i njegovih 
kliznih ležajeva. Kardanske osovine, koje se nalaze između motora i mjenjača te između mjenjača i pogonske osovine, restaurirane su u tvrtki Kardany Velká Biteš. Niz restauriranih ili novih sitnih dijelova još je bilo moguće nabaviti u specijaliziranim trgovinama pa izrada atipičnih ispušnih cijevi i prigušivača naručena je od tvrtke Ronelt.

\section{Staklarski radovi}

Nakon montaže poda pristupilo se ostakljivanju prozora. Sačuvana originalna sigurnosna stakla oprana su i postavljena pomoću specijalnih gumenih profila. Premda je tijekom više od 50 godina nastao velik broj raznih gumenih profila, i dalje se $u$ katalogu češke tvrtke Gumex mogu naći odgovarajući profili od elastomera EPDM ili SBR crne boje. Tvrtka Fatra Napajedla osigurala je izradu plastičnih profila od Novoplasta (PVC - polivinilklorid). Ti su se plastični profili u prošlosti vrlo često koristili zajedno s letvicama od aluminija u svim vrstama vozila javnog prijevoza. Te je letvice, kao i okvire bočnih prozora, potrebno pažljivo polirati, što je vrlo zahtjevno zbog velike dužine nekih vanjskih letvica.

\section{Tapetarski radovi}

Restauriranje sjedala sljedeća je važna etapa u konzerviranju i restauriranju muzejskih vozila. Tapecirana sjedala često su znatno oštećena te ih je nužno iznova tapecirati novom umjetnom kožom. Sjedala autobusa Karosa ŠL 11.1305 sastavljena su od donjeg dijela i dva naslona koji su pričvršćeni na čelični kostur. Stoga je odabrana nova crvena umjetna koža koja je u potpunosti odgovarala izvornom materijalu, a čelični su kosturi sjedala lakirani pečenim lakom DuPont Pulverlack sive boje nijanse RAL 7035 (sl. 11 i 12).

\section{Stolarski radovi}

Autobusni pod je načinjen od vodootporne šperploče. Pojedini rezani dijelovi pričvršćeni su vijcima na čelične profile okvira kolnog ormara. Vodootporna je šperploča $\mathrm{s}$ vanjske strane pokrivena lijepljenom podnom oblogom. U sredini se poda nalazi crna rebrasta guma koju i danas nudi tvrtka Gumex, dok je glatka siva podna obloga Linolit ispod sjedala trebala biti zamijenjena novim materijalom, podnom oblogom Super iste sive boje. Od kraja pedesetih godina $u$ češkim su se vozilima javnog prijevoza kao unutarnja obloga koristile ploče od umakarta s karakterističnim uzorkom površine. Proizvodnja umakarta trajala je više od četrdeset godina u kemijskom poduzeću UMA Pardubice. Umakart znači umjetni karton, a u današnje vrijeme zamjenjuju ga HPL ploče (high presure laminat). Srećom je originalna unutarnja obloga od umakarta $u$ autobusu Karosa ŠL 11.1305 bila u vrlo dobrom stanju, te se mogla sačuvati i iznova iskoristiti tijekom restauratorskih radova (sl. 13).

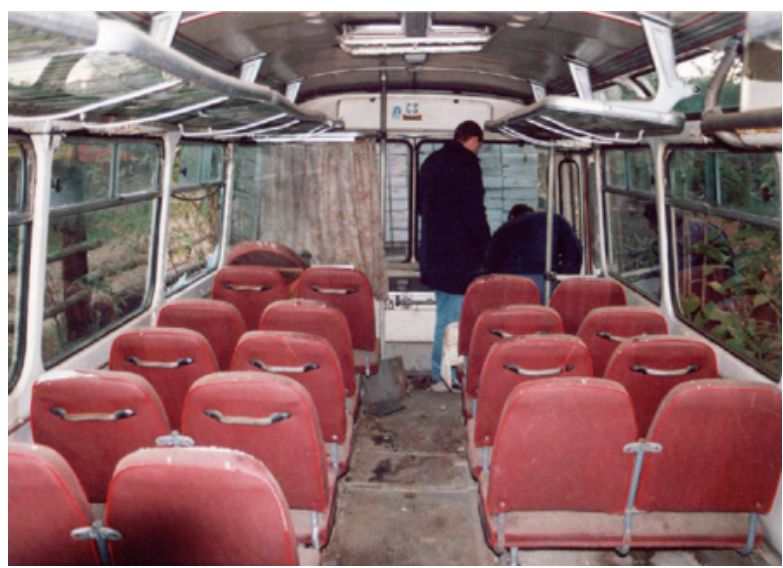

11. Zatečeno stanje interijera autobusa Karosa ŠL 11.1305 (TMB, snimka: T. Kocman, 2003.)

Condition of the interior of the Karos ŠL 11.1305 bus before conservation (TMB, T. Kocman, 2003)

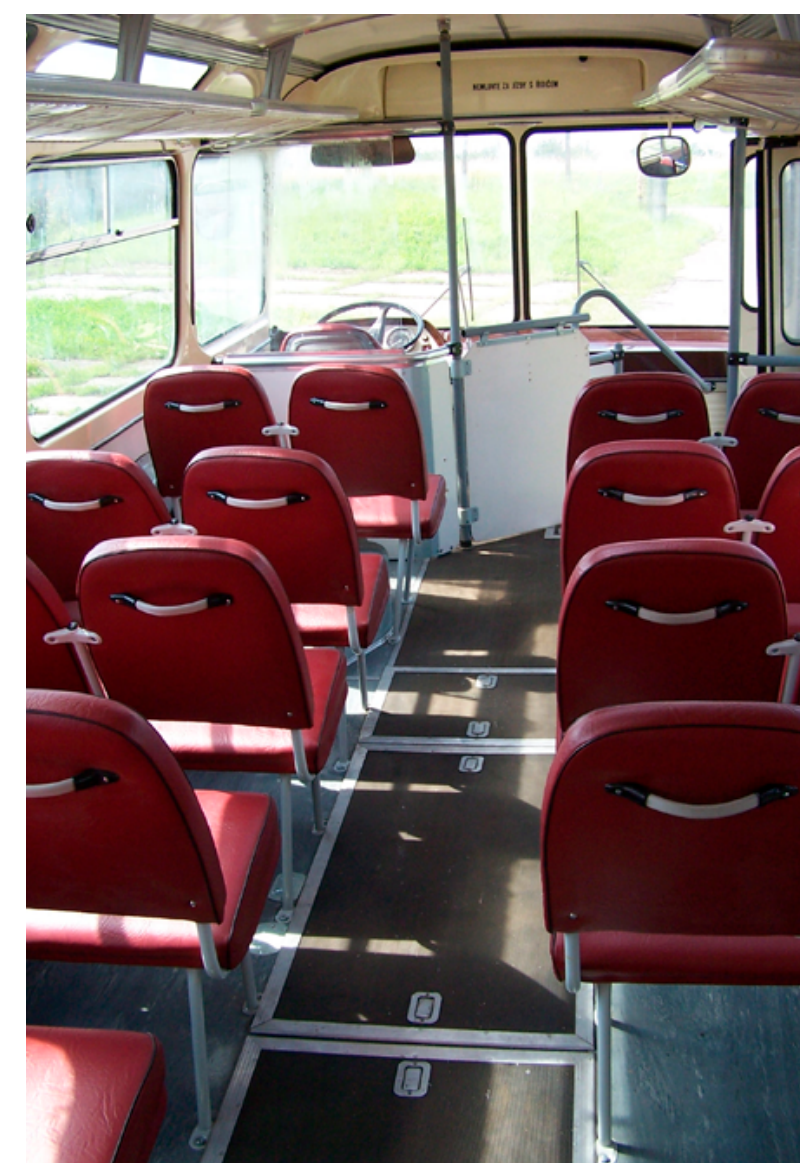

12. Stanje interijera autobusa Karosa ŠL 11.1305 nakon konzervatorskog-restauratorskog zahvata (TMB, snimka: T. Kocman, 2009.)

Condition of the interior of the Karos ŠL 11.1305 bus after conservation (TMB, T. Kocman, 2009)

\section{Opremanje interijera autobusa}

Završna etapa konzervatorsko-restauratorskih radova na autobusu Karosa ŠL 11.1305 obuhvatila je montažu sjedala, polica za prtljagu, opreme vozačke kabine te svih 


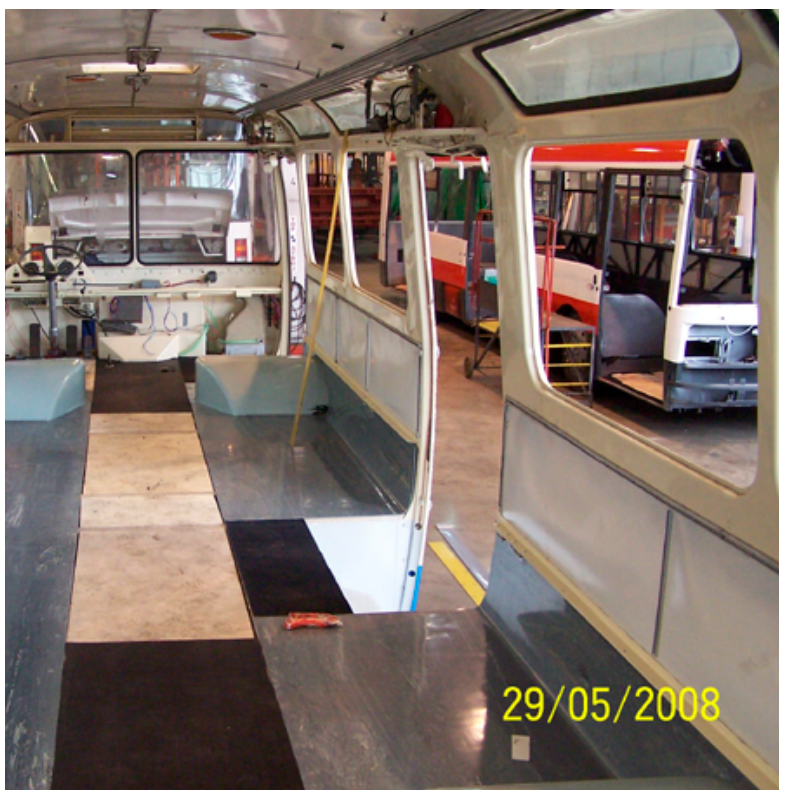

13. Lijepljenje novih podnih obloga u interijeru autobusa Karosa ŠL 11.1305 (TMB, snimka: T. Kocman, 2008.)

Gluing new flooring in the Karos ŠL 11.1305 bus (TMB, T. Kocman, 2008)

ostalih dijelova. Restauriranje autobusa Karosa $\check{S} L 11.1305$ potpuno je završeno nakon pet godina radova, u srpnju 2009. godine. Taj je autobus postao najstarije vozilo tipa Š $11 \mathrm{u}$ voznome stanju te je ove godine proslavio pedeseti rođendan.

\section{Financijski troškovi}

Konzervatorsko-restauratorski radovi pretežno se financiraju iz fondova Ministarstva kulture. Riječ je o fondovima Integriranog sustava zaštite muzejskih predmeta namijenjenih, među ostalim, njihovom zahtjevnom restauriranju. Tehnički je muzej u Brnu je za restauriranje autobusa Karosa ŠL 11.1305 dobio 605000 čeških kruna (oko 24 000 eura). Budući da je finalizacija restauratorskih radova realizirana u radionici Tehničkog muzeja uz besplatnu pomoć nekolicine dragovoljnih suradnika, ukupni su financijski troškovi znatno smanjeni.

\section{Predstavljanje restauratorskih radova na autobusu}

Tijekom zadnjih dvanaest godina restaurirani je autobus Karosa ŠL 11.1305 često sudjelovao na raznim događanjima i vožnjama za širu javnost koje Tehnički muzej održava svake godine. Istaknuti se može, primjerice, Přehlídka automobilové techniky (Smotra automobilske tehnike), koja se svake godine održava posljednjeg vikenda $u$ travnju u spremištu Tehničkog muzeja, Muzejska noć, koja se održava tijekom svibnja, ili priredba Parní Olympia, koja se održava početkom lipnja. U gradiću Modřicama, uz trgovački je centar Olympia izgrađena velika vrtna željeznica na kojoj se svake godine odvijaju međunarodni susreti modelara te vožnje muzejskih autobusa. Također, uz suradnju s Gradskim prometnim poduzećem u Brnu, jednog lipanjskog vikenda već više od dvadeset godina gradom prolaze muzejski tramvaji, trolejbusi i autobusi. Vrijedna je i proslava 150. obljetnice javnog gradskog prijevoza u Brnu, potkraj kolovoza 2019. godine. Autobus Karosa ŠL 11.1305 posjetio je i druge češke gradove, kao što su Liberec, Jablonec nad Nisou ili Zlín. Do kraja 2020. godine taj je restaurirani autobus prošao više od 7 000 kilometara.

\section{Zaključak}

Očuvanjem starodobnih vozila javnog prijevoza u Češkoj bavi se samo jedna muzejska ustanova - Tehnički muzej u Brnu. Dakako, zahvaljujući aktivnostima pojedinih prijevozničkih poduzeća, postoje i druge slične zbirke. Radi se prije svega o zbirci Gradskog prometnog poduzeća glavnog grada Praga, gdje je u remizi Střešovice nastao Muzej Prometnog poduzeća grada Praga, zatim u gradovima Plzeňu, Ostravi, Zlínu, ili u glavnom gradu Slovačke, Bratislavi. Privatne osobe i udruge također posjeduju neka starodobna vozila, a u očuvanju muzejskih autobusa sudjeluju i privatna prometna poduzeća, kao što su Jihotrans České Budějovice, ZDAR Ždár nad Sázavou i ČSAP Nymburk. Bivši vlasnik tvrtke ČSAP Nymburk osnovao je Muzej velikih volana u Loučeňu (sl. 14 i 15).

Kao strane primjere moguće je navesti Muzej budimpeštanskog prometnog poduzeća u gradiću Senandriji, zbirku muzejskih kola MPK Krakow te bečki Muzej tramvaja u spremištu Erdberg. U Austriji postoje još tri muzeja tramvaja, u Mariazellu, Grazu i Innsbrucku, a stručnoj su javnosti svakako poznati muzeji tramvaja u Bazileju, Amsterdamu, te $u$ blizini engleskog grada Cricha. Navedeni popis nije posve cjelovit. Samo u Europi postoji oko tisuću vozila javnog prijevoza koja su restaurirana na vrhunski i stručan način. Usporedi li se njihovo sadašnje stanje s prethodno ostvarenim renoviranjem, nameće se zaključak kako se uvijek koristi princip vraćanja ili u izvorno stanje vozila ili u stanje koje odgovara određenom periodu njihova prometovanja. Ujedno dolazi do uklanjanja neizvornih naknadnih promjena koje nisu u skladu s tipičnom konstrukcijom renoviranog vozila.

Konzervatorsko-restauratorski postupak može se sagledati kroz sljedeće korake:

\section{Kolni ormar}

- uklanjanje vanjske i unutarnje oplate, brušenje ili pjeskarenje kostura kolnog ormara ili popravak i zamjena dijelova kolnog ormara oštećenih korozijom, antikorozivna zaštita, nova limena oplata, vanjsko lakiranje

- zamjena oštećenih drvenih dijelova te popravak oplate krovnih površina postavljanjem novog platna u kolima kombinirane konstrukcije (čelik, drvo) 

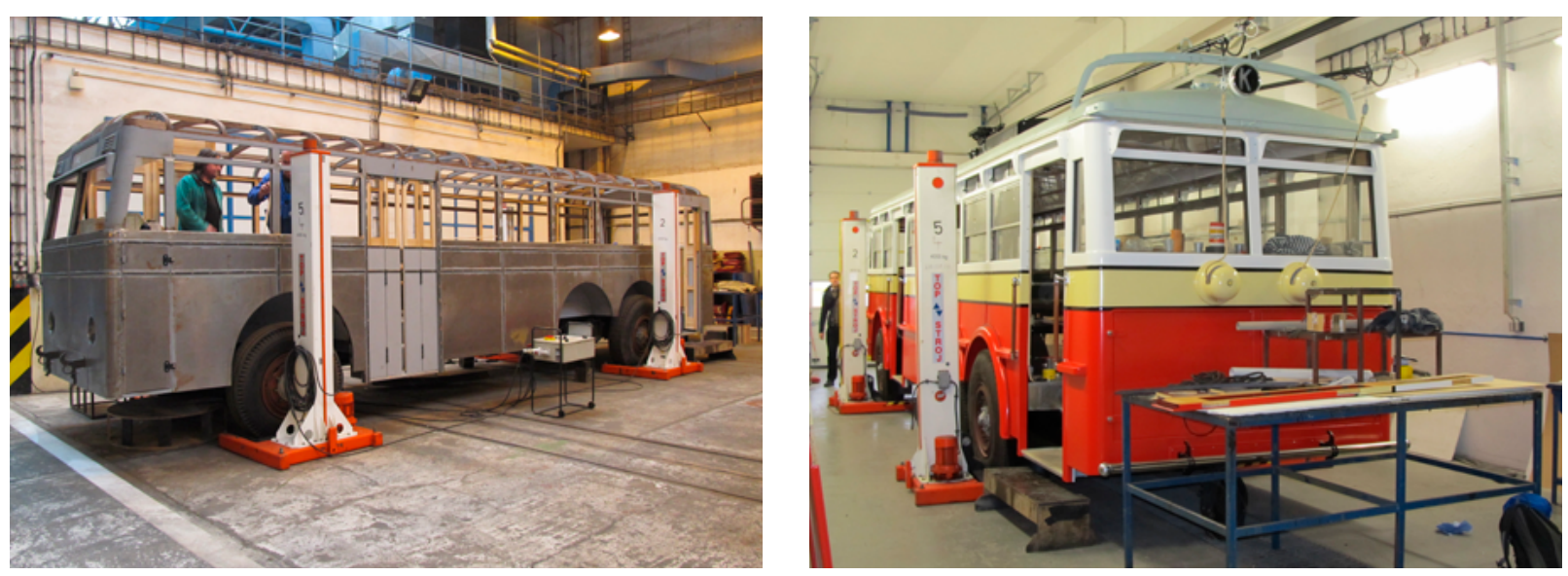

14. - 15. Primjer vrhunske razine obnove povijesnog vozila javnog prijevoza nesumnjivo je prototip trolejbusa Praga TOT iz 1936. godine. Sačuvan je bio tek njegov torzo, a nakon višegodišnjih restauratorskih radova u Muzeju Gradskog prometnog poduzeća glavnog grada Praga, u središnjoj radionici u Hostivařu, ulazi u završnu fazu. Trolejbus će biti vraćen u izvorno stanje, iz doba dok se još vozilo po lijevoj strani kolnika. Svi drveni dijelovi kolnog ormara - uključujući krila ulaznih vrata - u potpunosti su ponovo izrađeni. Kroz zahtjevan proces restauriranja prošao je i čelični kostur kolnog ormara te je postavljena potpuno nova limena oplata. (TMB, snimka: T. Kocman, 2015. i 2018.)

One example of excellent restoration of a public transport vehicle is undoubtedly the 1936 Prague TOT trolleybus prototype. Only its body had been preserved, and, after many years at the central workshop in Hostivař of the Museum of the City Transport Company in Prague, the conservation process is entering its final phase. The trolleybus will be restored to its original condition, when it was still driven on the left side of the road. All the wooden parts of the coachwork - including the front door wings - have been completely rebuilt. The steel frame of the coachwork also underwent a demanding restoration process, and a completely new sheet-metal frame was installed. (TMB, T. Kocman, 2015 and 2018)

- montaža kablova električnih krugova visokog i niskog napona, montaža cijevi zračnih i hidrauličnih krugova

- postavljanje unutarnje oplate, drvenog poda, te gumene podne obloge

2. Vučni agregat i električna oprema

- restauriranje dizelskog motora, mjenjača, a kod električnih vozila restauriranje vučnih elektromotora, otpornika za vožnju i kočenje, kontrolera, sklopki, spajanje vučnih, upravljačkih i pomoćnih električnih krugova

3. Podvozje

- retauriranje kočionog sustava i pneumatskih krugova, opruge (kovanje listova opruga), kod tračničkih vozila tokarenje profila vijenaca kotača ili njihova zamjena. Ponekad treba izraditi sasvim nove kolne slogove i zupčanike.

4. Kompletiranje vozila

- ostakljenje prozora sigurnosnim staklom, uključujući izradu atipičnih gumenih profila, montaža restauriranih sjedala, rukohvata, opreme vozačke kabine i kondukterskog mjesta, pogona vrata, vanjskih i unutarnjih letvica od aluminija ili drva

- montaža odbojnika, oduzimača struje, rasvjete, žmigavaca, retrovizora i sl.

Navedene principe konzervatorsko-restauratorskih radova na području javnog gradskog prijevoza Tehnički muzej u Brnu primjenjuje od vremena nastanka kolekcije muzejskih vozila. Ipak, postoje i muzejska vozila javnog prijevoza koja su očuvana ili samo djelomično restaurirana u stanju u kojem su zatečena. S obzirom na njihovo tehničko stanje također če biti potrebno što prije osigurati cjeloukupno konzerviranje i restauriranje. Kao primjer se mogu navesti autobusi Karosa B 732.20, Škoda $21 \mathrm{Ab}$, Ikarus 280 i Ikarus 412. Riječ je o novijim vozilima koja su proizvedena u razdoblju od 1988. do 1996. godine. Međutim, nabava potrebnih originalnih rezervnih dijelova s vremenom će biti sve teža, a možda i nemoguća. U restauratorskim radovima muzejskih vozila javnog prijevoza, pod stručnim nadzorom, sudjeluju vrlo marljivi radnici pojedinih prometnih poduzeća te obrtnici. Neki se od njih poviješću gradskog javnog prijevoza bave samo kao hobijem. Skrb za muzejske predmete u muzejima tramvaja obično se zasniva na radovima i aktivnostima niza volonterskih suradnika. Ti su ljudi uspjeli očuvati nazanemariv dio europske kulturne baštine.

Češka dosad nije raspolagala odgovarajućim financijskim sredstavima koja su potrebna za restauriranje postojećih starodobnih vozila javnog gradskog prijevoza, očuvanih kako u muzejskim ustanovama tako i kod privatnih vlasnika. Tehnički je muzej u Brnu, u okviru Metodičkog centra za konzervaciju, u stanju pojačati ulogu stručnog odjela koji bi se mogao sustavno posvetiti konzerviranju i restauriranju vozila javnog prijevoza, a ujedno pružati konzultacijske djelatnosti i drugim subjektima čiji je cilj očuvanje muzejskih vozila javnog gradskog prijevoza. 


\section{Bilješke}

1. Članak je nastao kao rezultat institucionalne potpore Ministarstva kulture Republike Češke dugoročnom razvoju istraživačke ustanove Tehničkog muzeja u Brnu.

2. Testiranje vozila u nadležnosti je češkog kluba vlasnika starodobnih vozila udruženih u organizaciji FKHV (Federacija kluba starodobnih vozidla, www.fkhv.cz). FKHV je član međunarodne organizacije FIVA (Fédération Internationale des Véhicules Anciens) tako da se testiranje održava u skladu s preporukama FIVA-e (npr. testirati se mogu vozila od 30 godina starosti). Klubska komisija procijenjuje povijesno stanje starodobnih vozila, dok županijske komisije ispituju njegovo tehničko stanje. Na temelju zapisnika o testiranju vlasnik dobiva poseban registracijski broj starodobnog vozila, koji označen slovom „V“ i zelenom bojom.

3. Vyhláška MD č. 355/2006 Sb. o stanovení způsobu a podmínek registrace, provozu a podmínek testování historických a sportovních vozidel, ve znění vyhlášky MD č. 144/2012 Sb.

4. Vyhláška MD č. 173/1995 Sb., kterou se vydává dopravní rád drah, ve znění vyhlášky MD č 242/1996 Sb., vyhlášky MDS č. 174/2000

\section{Literatura}

TOMÁŠ KOCMAN, Silniční vozidla městské hromadné dopravy ve sbírkovém fondu Technického muzea v Brně, Brno, 2019.

LUBOMÍR KYSELA, Prưvodce Muzeem městské hromadné dopravy v Praze, Praha, 2006.

\section{Kratice}

TMB - Tehnički muzej u Brnu
Sb., vyhlášky č. 133/2003 Sb., vyhlášky č. 57/2013 Sb., vyhlášky č. 7/2015 Sb., vyhlášky č. 78/2017 Sb. a vyhlášky č. 47/2018 Sb. 5. Vyhláška MD č. 100/1995 Sb., kterou se stanoví podmínky pro provoz, konstrukci a výrobu určených technickúch zařizení a jejich konkretizace (Řád určených technických zařizeni), ve znění vyhláškyč. 279/2000 Sb., nařizení vlády č. 352/2000 Sb., vyhlášky č. 210/2006 Sb. a vyhlášky č. 128/2017 Sb.

6. Torinska povelja, https://www.fkhv.cz/fiva/turinska-charta/; u originalu Charter of Turin, https://fiva.org/wp-content/ uploads/2019/08/Charter-of-Turin-Glossary-30-06-16-1.pdf 7. Odlukom vlade Republike Češke, u Tehničkom je muzeju u Brnu 2003. godine osnovan Metodički centar za konzervaciju, kao referentni centar konzervatorsko-restauratorske djelatnosti, s restauratorskom radionicom koja pruža stručnu pomoć svim češkim muzejima.

JIŘí BOHÁČEK, PETR MITÁČEK, Katalog historických vozidel, Ostrava, 2001.

JAN BATĚK, Autobusy Karosa ŠM11 v provozu a údržbě, Praha, 1975.

\section{Summary}

Tomáš Kocman

\section{THE COLLECTION OF PUBLIC-TRANSPORT VEHICLES AT THE TECHNICAL MUSEUM IN BRNO: CONSERVATION OF THE KAROS BUS, ŠL 11.1305}

Public-transport vehicles in the collection of the Technical Museum in Brno are characterized by specific conservation and restoration. This is the largest collection in the Czech Republic and contains more than one hundred trams, trolleybuses, buses and their trailers. There are also a small number of steam and electric locomotives, railway cars and special impellers. The conservation of the public-transport vehicles is carried out in professional workshops where present-day trams, trolleybuses and buses are repaired and inspected. Restoring them to their function is important so that operational vehicles can be presented to the general public. So far, the only way of presenting public transport vehicles from the collection of the Technical Museum in Brno has been occasional rides through the streets of the city. In order to be able to use refurbished public transport vehicles in this way, it is necessary to comply with strict legislative requirements.
Conservation and restoration of museum public-transport vehicles includes repairing their basic elements: coachwork, traction unit or electrical equipment, and chassis.

The Technical Museum acquired its public-transport vehicles after they had been scrapped. All the parts of these vehicles were worn out. The load-bearing elements of the coachwork were especially corroded, and it is not advisable to keep only partially-preserved vehicles in the condition in which they were acquired. With more than 50 years of experience, achieved during the formation of the collection of public-transport vehicles, it can be concluded that the Technical Museum in Brno considers the best method to preserve and restore a vehicle is an overhaul, and a return to its proper historical appearance in accordance with the principles of the International Federation of Historic Vehicles, FIVA, formulated in several articles of the Turin Charter. A characteristic example of this type 
of procedure is the conservation of the famous Czech bus, Karos ŠL11.1305. The vehicle is one of the first buses of the Czechoslovak state bus carrier, ČSAD, intended for regional transport. The Technical Museum in Brno received the Karos SL11.1305 bus in 2004. The entire bus was preserved, although it was quite damaged, because it was left in the open by the previous owner, and exposed to floods in 1997. Restoration of the Karos ŠL11.1305 bus took 5 years. The collection curator is fully responsible for making decisions on the necessary conservation and restoration of museum public-transport vehicles, and the condition and phase of renovation of each individual object. The Technical Museum in Brno strives to return every public-transport vehicle to its original and running condition, to the extent that that can be achieved.

KEYwORDs: technical museum, public transport, tram, trolleybus, bus, vintage vehicle, conservation, restoration 
